\title{
Uji Toksisitas Akut Ekstrak Air Dan Ekstrak Etanol Daun Kacapiring (Gardenia jasminoides Ellis) Terhadap Larva Artemia Salina Leach Dengan Metode Brine Shrimp Lethality Test (BSLT)
}

\author{
Nuralifah ${ }^{1}$, Parawansah ${ }^{2}$, Hasniana Nur ${ }^{1}$ \\ 1 Jurusan Farmasi, Fakultas Farmasi, Universitas Halu Oleo, Kendari, Indonesia. \\ ${ }^{2}$ Fakultas Kedokteran, Universitas Halu Oleo, Kendari, Indonesia. \\ *E-mail:nuralifah@uho.ac.id
}

\section{Article Info:}

Received: 25 April 2021

in revised form: 15 Mei 2021

Accepted: 30 Mei 2021

Available Online: 30 Mei 2021

\section{Keywords:}

Gardenia jasminoides Ellis

BSLT

Artemia salina Leach

Acute Toxicity

Corresponding Author:

Nuralifah

Jurusan Farmasi

Fakultas Farmasi

Universitas Halu Oleo

Kendari

Indonesia

E-mail: nuralifah@uho.ac.id

\section{ABSTRACT}

A toxicity test is a test to detect the toxic effect of a substance on a biological system and to obtain typical dose-response data from the test preparation. This study aims to determine the content of secondary metabolites from the aqueous extract and ethanolic extract of gardenia leaves, characterization of gardenia leaf extract, and acute toxicity using the BSLT method against Artemia salina Leach shrimp larvae.

Phytochemical screening tests were carried out by the color change method which included the alkaloid test, flavonoid test, tannin test, saponin test, and terpenoid test. Extract characterization tests include determination of water-soluble extract, determination of ethanol-soluble extract, determination of water content, and determination of ash content. Acute toxicity test using the Brine Shrimp Lethality Test (BSLT) method using Artemia salina Leach shrimp larvae.

The results of the phytochemical screening test for the aqueous extract of gardenia leaves showed positive results on saponins, while the phytochemical screening tests on ethanol extracts showed positive results on alkaloids, flavonoids, saponins, tannins, and terpenoids. The results of the characterization test on the aqueous extract of gardenia leaves were that the ethanolsoluble extract content was $20.19 \%$, the water-soluble extract content was $23.17 \%$, the water content was $99.13 \%$ and the ash content was $0.29 \%$. Meanwhile, in the ethanolic extract of gardenia leaves, the ethanol-soluble extract content was $60.80 \%$, the water-soluble extract content was $57.14 \%$, the water content was $7.87 \%$ and the ash content was $3.22 \%$. The results show that gardenia leaves are not toxic with the LC50 value of the water extract of the gardenia leaves is $1399.64 \mathrm{~g} / \mathrm{mL}$ and the LC50 value of the ethanolic extract of the gardenia leaves is 1080.96 so that it can be used as traditional medicine. 
How to cite (APA $6^{\text {th }}$ Style):

Nuralifah., dkk. (2021). Uji Toksisitas Akut Ekstrak Air Dan Ekstrak Etanol Daun Kacapiring (Gardenia jasminoides Ellis) Terhadap Larva Artemia Salina Leach Dengan Metode Brine Shrimp Lethality Test (BSLT). Indonesian Journal of Pharmaceutical (e-Journal), 1(1), 98-106.

\begin{abstract}
ABSTRAK
Uji toksisitas adalah suatu uji untuk mendeteksi efek toksik suatu zat pada sistem biologi dan untuk memperoleh data dosis-respon yang khas dari sediaan uji. Penelitian ini bertujuan untuk mengetahui kandungan metabolit sekunder dari ekstrak air dan ekstrak etanol daun kacapiring, karakterisasi ekstrak daun kacapiring dan toksisitas akut menggunakan metode BSLT terhadap larva udang Artemia salina Leach.

Pengujian skrining fitokimia dilakukan dengan metode perubahan warna yang meliputi uji alkaloid, uji flavonoid, uji tanin, uji saponin dan uji terpenoid. Pengujian karakterisasi ekstrak meliputi penetapan sari larut air, penetapan sari larut etanol, penetapan kadar air dan penetapan kadar abu. Pengujian toksisitas akut menggunakan metode Brine Shrimp Lethality Test (BSLT) dengan menggunakan larva udang Artemia salina Leach.

Hasil pengujian skrining fitokimia ekstrak air daun kacapiring menunjukkan hasil positif pada saponin, sedangkan uji skrining fitokimia pada ekstrak etanol menunjukkan hasil positif pada alkaloid, flavonoid, saponin, tanin dan terpenoid. Hasil pengujian karakterisasi pada ekstrak air daun kacapiring adalah pada kadar sari larut etanol adalah 20,19\%, kadar sari larut air adalah $23,17 \%$, kadar air 99,13 \% dan kadar abu adalah 0,29\%. Sedangkan pada ekstrak etanol daun kacapiring adalah kadar sari larut etanol adalah $60,80 \%$, kadar sari larut air adalah $57,14 \%$, kadar air $7,87 \%$ dan kadar abu adalah 3,22\%. Hasil menunjukan bahwa daun kacapiring tidak bersifat toksik dengan nilai LC $_{50}$ ekstrak air daun kacapiring adalah 1399,64 $\mu \mathrm{g} / \mathrm{mL}$ dan nilai $\mathrm{LC}_{50}$ ekstrak etanol daun kacapiring adalah 1080,96 sehingga dapat dimanfaatkan sebagai obat tradisional.
\end{abstract}

Kata Kunci: Gardenia jasminoides Ellis, BSLT, Artemia salina Leach, Toksisitas Akut

\title{
1. Pendahuluan
}

Uji toksisitas adalah suatu uji untuk mendeteksi efek toksik suatu zat pada sistem biologi dan untuk memperoleh data dosis-respon yang khas dari sediaan uji. Bahan alam yang diduga berpotensi sebagai obat maupun secara empiris telah digunakan masyarakat sebagai obat, diawali dengan uji toksisitas praklinik untuk memprediksi tingkat keamanannya, kemudian dilanjutkan dengan uji farmakologi lainnya. Pengujian toksisitas dapat dilakukan secara in vitro maupun in vivo (Frengki, Roslizawaty, 2014). Manfaat tanaman obat adalah karena zat yang dikandungnya menghasilkan efek fisiologis pada tubuh manusia. Beberapa contoh zat tersebut adalah alkaloid, minyak atsiri, tanin, resin, dan zat berkhasiat lainnya (Olowa \& Nuneza, 2013). Pengujian toksisitas dapat dilakukan dengan menggunakan metode Brine Shrimp Lethality Test (BSLT). penggunaan larva udang Artemia salina untuk uji BSLT ini ialah sifatnya yang peka terhadap bahan uji, waktu siklus hidup yang lebih cepat, dan mudah dibiakkan. Sifat peka Artemia salina kemungkinan disebabkan oleh keadaan membran kulitnya yang sangat tipis sehingga memungkinkan terjadinya difusi zat dan lingkungan yang mempengaruhi metabolisme dalam tubuhnya (Mudjiman, 1988).

Menurut World Health Organization (WHO), saat ini, 80\% populasi dunia bergantung pada tanaman untuk perawatan kesehatan utamanya. Salah satu tanaman yang 
digunakan eleh masyarakat secara empiris adalah tanaman kacapiring (Gardenia jasminoides). Daun kacapiring yang berwarna hijau tua memiliki kandungan klorofil yang merupakan pigmen alami yang terdapat pada dedaunan. Selain klorofil, daun kacapiring juga mengandung senyawa flavonoid, saponin, tanin, asam galat dan steroid Tanaman kacapiring memiliki banyak manfaat, diantaranya dapat dijadikan minyak atsiri yang dihasilkan dari bunga, dan daunnya dapat digunakan sebagai obat demam, sesak napas, tekanan darah tinggi (hipertensi) dan sariawan (obat kumur). (Mutiah dkk., 2018 ; Dalimartha, 2006).

\section{Metode}

Penelitian ini merupakan penelitian eksperimental dengan post test only control group design untuk menguji toksisitas dari ekstrak etanol dan ekstrak air Gardenia jasminoides terhadap larva Artemia salina Leach menggunakan metode BSLT.

\subsection{Bahan}

Bahan-bahan yang akan digunakan pada penelitian yaitu ekstrak dan ekstrak air daun tanaman kacapiring (Gardenia jasminoides Ellis), Artemia salina Leach, etanol 96\%, aquadest, air laut, kertas saring, DMSO (Dimetilsulfoksida), tepung jagung, telur Artemia salina L. (Great Salt Lake), pereaksi Dragendorf, Pereaksi Meyer, $\mathrm{HCl}, \mathrm{FeCl}_{3}$, Magnesium, kloroform. , asam sulfat pekat dan asam asetat anhidrat.

\section{2..2 Determinasi dan Karakteristik Sampel}

Determinasi tanaman dilakukan di Laboratorium Biologi Fakultas Matematika dan Ilmu Pengetahuan Alam, Universitas Halu Oleo. Karakteristik sampel meliputi penetapan kadar sari larut dalam air, penetapan kadar sari larut dalam etanol, penetapan kadar abu dan penetapan kadar air dilakukan di Laboratorium Fakultas Farmasi UHO

\subsection{Persiapan Sampel}

Pengambilan sampel daun daun kacapiring dilakukan di Desa Mowila, Kecamatan Mowila, Kabupaten Konawe Selatan, Sulawesi Tenggara. Preparasi sampel dilakukan dengan pengumpulan dan pemilahan daun Gardenia jasminoides, sortasi basah, pencucian, perajangan, pengeringan dan sortasi kering. Setelah kering, sampel kemudian dihaluskan dengan pencacah elektrik sehingga dihasilkan simplisia yang berbentuk haksel kecil dan kemudian disimpan dalam wadah bersih, kering dan terlindung dari cahaya.

\subsection{Pembuatan Ekstrak Air}

Daun kacapiring yang telah diperoleh cuci dengan air bersih. daun kacapiring ditimbang, ditambahkan pelarut akuades dengan perbandingan 1:1. Larutan stok dibuat dengan cara ditimbang bahan uji sebanyak $100 \mathrm{mg}$, kemudian dilarutkan dengan air laut sebanyak $25 \mathrm{ml}$, hingga diperoleh konsentrasi larutan stok $4000 \mathrm{ppm}$. Konsentrasi larutan uji untuk BSLT adalah 10 ppm, 100 ppm, 250 ppm, 500 ppm, 750 ppm, 1000 ppm.

\subsection{Pembuatan Ekstrak Etanol}

Metode ekstraksi yang digunakan yaitu dengan metode maserasi. Serbuk daun kacapiring dimasukkan ke dalam wadah tertutup dan direndam dengan menggunakan 
pelarut etanol. Pemisahan residu dan filtrat dilakukan setiap $3 \times 24$ jam diiringi penggantian pelarut yang sama. Filtrat dikumpulkan dan dipekatkan dengan rotary vacuum evaporator pada suhu $50^{\circ} \mathrm{C}$ hingga diperoleh ekstrak etanol kental daun Gardenia jasminoides Ellis dan dihitung nilai rendamennya. Larutan stok dibuat dengan cara ditimbang bahan uji sebanyak $100 \mathrm{mg}$, kemudian dilarutkan dengan DMSO beberapa tetes dan dicukupkan dengan air laut sebanyak $25 \mathrm{ml}$, hingga diperoleh konsentrasi larutan stok 4000 ppm. Konsentrasi larutan uji untuk BSLT adalah 10 ppm, 100 ppm, 250 ppm, 500 ppm, 750 ppm, 1000 ppm.

\subsection{Uji Toksisitas Sampel dengan Metode BSLT}

Uji toksisitas dilakukan dengan metode BSLT dengan cara disiapkan vial untuk tiap kelompok sesuai tingkat konsentrasi dan dilakukan replikasi sebanyak 3 kali. Uji toksisitas dilakukan dengan memasukkan 10 larva udang berumur 48 jam bersamaan air laut ke dalam vial yang telah berisi $2,5 \mathrm{ml}$ larutan ekstrak. Tabung uji lalu diletakkan di bawah penerangan lampu 5 watt selama 24 jam, kemudian dihitung jumlah larva udang yang mati. Kriteria standar untuk menilai kematian larva udang adalah bila larva udang tidak menunjukkan pergerakan selama beberapa detik observasi (Sari, 2006). Tabel kelompok perlakuan hewan uji dapat dilihat pada Tabel 3.

Tabel 3.Kelompok perlakuan terhadap hewan uji

\begin{tabular}{|c|c|c|}
\hline No. & $\begin{array}{l}\text { Kelompok } \\
\text { perlakuan }\end{array}$ & Perlakuan \\
\hline 1 & K & 10 larva udang tanpa pemberian ekstrak tumbuhan \\
\hline 2 & P1 & $\begin{array}{l}10 \text { larva udang yang diberi ekstrak tumbuhan dengan } \\
\text { konsentrasi } 10 \mathrm{ppm} \text { dalam media }\end{array}$ \\
\hline 3 & P2 & $\begin{array}{l}10 \text { larva udang yang diberi ekstrak tumbuhan dengan } \\
\text { konsentrasi } 100 \mathrm{ppm} \text { dalam media }\end{array}$ \\
\hline 4 & P3 & $\begin{array}{l}10 \text { larva udang yang diberi ekstrak tumbuhan dengan } \\
\text { konsentrasi } 250 \mathrm{ppm} \text { dalam media }\end{array}$ \\
\hline 5 & P4 & $\begin{array}{l}10 \text { larva udang yang diberi ekstrak tumbuhan dengan } \\
\text { konsentrasi } 500 \mathrm{ppm} \text { dalam media }\end{array}$ \\
\hline 6 & P5 & $\begin{array}{l}10 \text { larva udang yang diberi ekstrak tumbuhan dengan } \\
\text { konsentrasi } 750 \mathrm{ppm} \text { dalam media }\end{array}$ \\
\hline 7 & P6 & $\begin{array}{l}10 \text { larva udang yang diberi ekstrak tumbuhan dengan } \\
\text { konsentrasi } 1000 \text { ppm dalam media }\end{array}$ \\
\hline
\end{tabular}

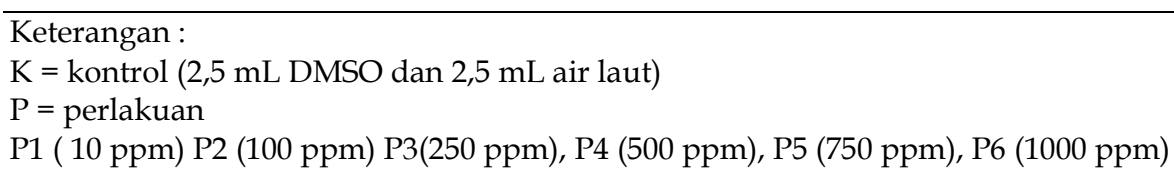

\section{Hasil dan Pembahasan}

\subsection{Determinasi Tanaman}

Determinasi tanaman kacapiring (Gardenia jasminoides Ellis.) dilakukan untuk memastikan kebenaran sampel yang digunakan dalam penelitian. Hasil identifikasi tanaman kacapiring yang dilakukan di Laboratorium Biologi FMIPA Universitas Halu Oleo menunjukkan bahwa tanaman yang digunakan adalah tanaman kacapiring (Gardenia jasminoides Ellis.) dengan kunci determinasi 1b-3b-4a. 


\subsection{Skrining Fitokimia}

Metode skrining fitokimia dilakukan dengan melihat reaksi pengujian warna dengan menggunakan suatu pereaksi warna. Skrining fitokimia meliputi pemeriksaan kandungan senyawa alkaloida, flavonoida, terpenoida/ steroida, tanin dan saponin (Minarno, 2015).

Tabel 7. Hasil skrining fitokimia ekstrak air daun kacapiring

\begin{tabular}{|c|c|c|c|c|c|c|}
\hline \multirow{2}{*}{ No. } & \multirow{2}{*}{$\begin{array}{c}\text { Uji } \\
\text { Fiokimia }\end{array}$} & \multirow{2}{*}{ Pereaksi } & \multicolumn{2}{|c|}{ Ekstrak Air } & \multicolumn{2}{|c|}{ Ekstrak Etanol } \\
\hline & & & Hasil & Ket & Hasil & Ket \\
\hline 1 & Alkaloid & Mayer & $\begin{array}{l}\text { Tidak terbentuk } \\
\text { endapan putih }\end{array}$ & - & $\begin{array}{c}\text { Terbentuk } \\
\text { endapan putih }\end{array}$ & + \\
\hline 2 & Flavonoid & $\begin{array}{l}\text { Serbuk Mg } \\
\quad+\mathrm{HCl}\end{array}$ & $\begin{array}{c}\text { Tidak terbentuk } \\
\text { warna merah, } \\
\text { kuning atau jingga }\end{array}$ & - & $\begin{array}{c}\text { Terbentuk } \\
\text { warna merah }\end{array}$ & + \\
\hline 3 & Tanin & $\mathrm{FeCl}_{3} 1 \%$ & $\begin{array}{c}\text { Tidak terbentuk } \\
\text { warna hijau } \\
\text { kehitaman }\end{array}$ & - & $\begin{array}{l}\text { Terbentuk } \\
\text { warna hijau } \\
\text { kehitaman }\end{array}$ & + \\
\hline 4 & Terpenoid & $\begin{array}{c}\text { Asam } \\
\text { asetat } \\
\text { anhidrat + } \\
\mathrm{H}_{2} \mathrm{SO}_{4}\end{array}$ & $\begin{array}{c}\text { Tidak terbentuk } \\
\text { warna merah atau } \\
\text { violet }\end{array}$ & - & $\begin{array}{c}\text { Terbentuk } \\
\text { warna merah }\end{array}$ & + \\
\hline 5 & Saponin & $\begin{array}{l}\text { Air panas } \\
\text { dan } \mathrm{HCl}\end{array}$ & $\begin{array}{c}\text { Terbentuk busa } \\
\text { yang stabil }\end{array}$ & + & $\begin{array}{c}\text { Terbentuk } \\
\text { busa yang } \\
\text { stabil }\end{array}$ & + \\
\hline
\end{tabular}

Keterangan :

$(-)$ : Tidak mengandung golongan senyawa metabolit sekunder

$(+)$ : Mengandung golongan senyawa metabolit sekunder

\subsection{Karakteristik Ekstrak}

Karakterisasi ekstrak daun kacapiring dilakukan sebagai upaya untuk mendapatkan ekstrak yang aman, memiliki mutu ekstrak yang baik, terstandar dan stabilitasnya teruji (Suharti et al., 2017). Karakterisasi yang dilakukan meliputi parameter spesifik ekstrak yaitu penentuan kadar sari larut air dan sari larut etanol, dan parameter non spesifik meliputi penentuan kadar air dan kadar abu.

Tabel 4. Hasil Karakterisasi Ekstrak Air dan Ekstrak Etanol

\begin{tabular}{lccc}
\hline \multicolumn{1}{c}{ Jenis Karakterisasi } & Ekstrak Air & Ekstrak Etanol & Standar \\
\hline Kadar air & $99,13 \%$ & $7,87 \%$ & $\leq 10 \%$ \\
\hline Kadar abu & $0,29 \%$ & $3,22 \%$ & $\leq 7 \%$ \\
\hline Kadar sari larut air & $23,17 \%$ & $57,14 \%$ & $\geq 18,00 \%$ \\
\hline Kadar sari larut etanol & $20,19 \%$ & $60,80 \%$ & $\geq 6,30 \%$
\end{tabular}

Berdasarkan tabel 4 Hasil pengujian kadar air pada ekstrak air daun kacapiring adalah 99,13\%. Kadar air pada ekstrak tidak memenuhi persyaratan yaitu $\leq 10 \%$ (Depkes, 2008). 
Tingginya kadar air pada ekstrak air ini dikarenakan daun yang digunakan untuk ekstraksi adalah daun segar dengan pelarut air sehingga kadar airnya tinggi. Tinggi rendahnya kadar air suatu ekstrak akan mempengaruhi mutu dari ekstrak tersebut, dimana semakin sedikit kadar air pada ekstrak maka semakin sedikit kemungkinan ekstrak terkontaminasi oleh pertumbuhan jamur. Kadar air dalam sediaan obat tradisional termasuk ekstrak tidak boleh melebihi batas 10\%. Kadar air yang melebihi 10\% dapat mengakibatkan ekstrak akan mudah ditumbuhi jamur (Ratnani dkk., 2015).

Penentuan kadar abu bertujuan untuk mengukur jumlah komponen anorganik atau mineral yang tersisa setelah proses pengabuan (Sutomo dkk., 2017). Kadar abu terkait dengan kemurnian dan kontaminasi dalam ekstrak. Kadar abu yang melebihi 7\% menunjukkan bahwa ekstrak tercemar logam-logam mineral yang akan menjadikan mutu atau kualitas ekstrak terganggu (Setyorini et al., 2016).

Penentuan kadar sari larut dalam air dan penetapan kadar sari larut etanol bertujuan untuk menunjukkan jumlah zat atau senyawa yang dapat disari oleh air maupun etanol. Penentuan kadar sari tersebut sangat penting, karena dapat memberikan gambaran mengenai besarnya zat atau senyawa terlarut dan merupakan bagian yang dimanfaatkan sebagai bahan obat (Zulharmita dkk., 2012). Kadar sari larut air dan sari larut etanol ekstrak etanol daun kacapiring yaitu sebesar 57,14\% dan 60,80 \%. Hal ini menunjukkan ekstrak daun kacapiring memiliki kelarutan yang lebih tinggi dalam etanol dibandingkan dalam air, ini berarti kandungan senyawa kimia yang larut dalam etanol lebih banyak dibandingkan senyawa kimia yang larut air karena sifat semipolar etanol yang dapat menarik senyawa yang bersifat polar maupun non polar, sedangkan air yang bersifat lebih polar dibandingkan etanol tidak mampu menarik senyawa nonpolar.

\subsection{Uji Toksisitas dengan Metode Brine Shrimp Lethality Test (BSLT)}

Metode BSLT (Brine Shrimp Lethality Test) sering digunakan untuk praskrining terhadap senyawa aktif yang terkandung dalam ekstrak tumbuhan karena sederhana, cepat, murah, mudah, dapat dipercaya, dan hasilnya representative (Made et al., 2013). Penggunaan Artemia salina Leach dalam metode BSLT dikarenakan memiliki kesamaan tanggapan/respon stress yang sama dengan manusia, yaitu respon perilaku dan fisiologis terhadap stressor lingkungan (Ajrina, 2013). Total larva yang digunakan pada seluruh percobaan dengan 3 kali percobaan/replikasi adalah 210 ekor. Total kematian larva diperoleh dengan menjumlahkan kematian larva, dibagi dengan total larva yang digunakan setiap konsentrasi dan dikalikan dengan 100\%. Nilai LC $_{50}$ dapat dilihat dari analisis probit dengan menggunakan MiniTab 17 for Windows pada tabel 5. 
Tabel 5. Hasil pengukuran nilai $\mathrm{LC}_{50}$ ekstrak air dan etanol daun kacapiring

\begin{tabular}{|c|c|c|}
\hline Sampel & $\begin{array}{c}\text { Konsentrasi } \\
(\mathrm{ppm})\end{array}$ & $\begin{array}{c}\mathrm{LC}_{50}(\mu \mathrm{g} / \mathrm{mL} / \\
\text { ppm) }\end{array}$ \\
\hline \multirow{7}{*}{$\begin{array}{l}\text { Ekstrak air daun } \\
\text { Kacapiring }\end{array}$} & 0 & \multirow{7}{*}{1399,64} \\
\hline & 10 & \\
\hline & 100 & \\
\hline & 250 & \\
\hline & 500 & \\
\hline & 750 & \\
\hline & 1000 & \\
\hline \multirow{7}{*}{$\begin{array}{l}\text { Ekstrak etanol daun } \\
\text { kacapiring }\end{array}$} & 0 & \multirow{7}{*}{1080,96} \\
\hline & 10 & \\
\hline & 100 & \\
\hline & 250 & \\
\hline & 500 & \\
\hline & 750 & \\
\hline & 1000 & \\
\hline
\end{tabular}

Berdasarkan tabel 5, ekstrak etanol dan ekstrak air daun kacapiring bersifat tidak toksik terhadap larva udang Artemia salina Leach. Menurut (Alam, 2002) ekstrak dikatakan bersifat toksik jika $\mathrm{LC}_{50}<1000 \mathrm{ppm}$. $\mathrm{LC}_{50}$ (Lethal Concentration 50) merupakan konsentrasi zat yang menyebabkan terjadinya kematian pada $50 \%$ hewan percobaan yaitu larva Artemia salina Leach. Hasil LC $_{50}$ ini sesuai dengan kurva yang ditunjukan pada Gambar 1 di bawah ini :

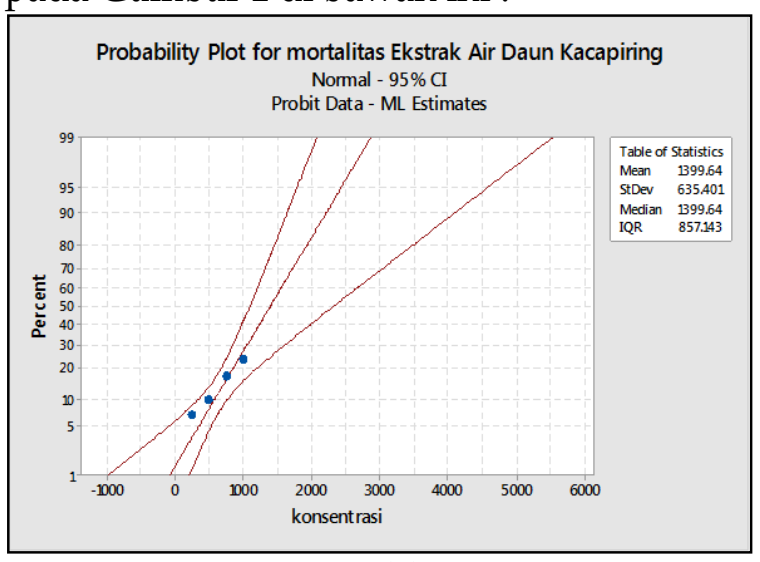

(a)

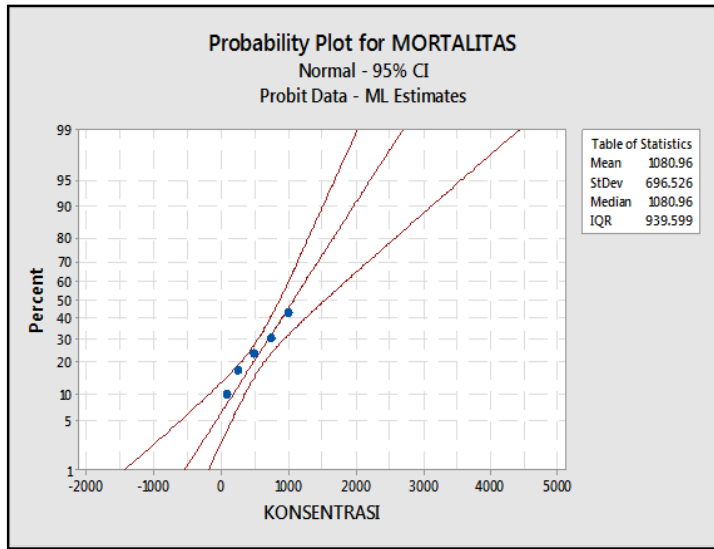

(b)

Gambar 1. Kurva analisis probit ekstrak daun kacapiring (a) ekstrak air (b) ekstrak etanol

Berdasarkan kurva pada Gambar 1 menunjukan bahwa setiap konsentrasi terjadi kenaikan tingkat mortalitas dari larva udang, hal ini disebabkan karena semakin tinggi konsentrasi suatu zat yang diberikan, semakin besar pula jumlah larva udang yang mati. Tingkat mortalitas yang paling tinggi terjadi pada konsentrasi $1000 \mu \mathrm{g} / \mathrm{mL}$. Dengan kata lain, semakin tinggi konsentrasi yang diberikan semakin besar pula keracunan yang ditimbulkan. Gejala keracunan timbul secara perlahan-lahan dalam waktu yang lama sesudah pemberian suatu zat. Artinya keracunan belum langsung terjadi pada saat pemberian suatu zat, namun zat tersebut diekskresikan dulu sehingga dengan waktu yang lama pengaruhnya baru terlihat. Mekanisme kematian larva Artemia salina Leach 
berhubungan dengan fungsi senyawa alkaloid, flavonoid dan saponin pada ekstrak daun kacapiring.

Cara kerja senyawa alkaloid adalah dengan bertindak sebagai stomach poisoning atau racun perut. Senyawa ini akan menghambat reseptor perasa pada daerah mulut larva. Hal ini mengakibatkan larva gagal mendapatkan stimulus rasa sehingga tidak mampu mengenali makanannya dan akibatnya larva mati kelaparan sedangkan senyawa golongan saponin dapat mengikat oksigen yang terdapat didalam air sehingga kadar oksigen didalam air menurun dan larva Artemia salina Leach dapat mengalami kematian karena kekurangan oksigen. Flavonoid bertindak sebagai antioksidan yang mencegah terjadinya fragmentasi DNA oksigen reaktif seperti radikal hidroksil yang memicu kerusakan sel yang mengawali timbulnya sel kanker. Senyawa golongan flavonoid juga dapat mempercepat proses apoptosis sel yang mengakibatkan kematian sel.

\section{Kesimpulan}

Berdasarkan hasil penelitian dapat disimpulakan bahwa Kandungan metabolit sekunder yang terdapat pada ekstrak etanol daun kacapiring yaitu flavonoid, alkaloid, tanin, terpenoid dan saponin sedangkan pada ekstrak air daun kacapiring yaitu saponin. Hasil uji toksisitas akut ekstrak air daun kacapiring terhadap hewan uji Artemia salina Leach senyawa memiliki nilai $\mathrm{LC}_{50}$ sebesar 1399,64 ppm dan uji toksisitas akut ekstrak etanol daun kacapiring terhadap hewan uji larva Artmemia salina Leach senyawa memiliki nilai LC $_{50}$ sebesar 1080,96 ppm dengan interprestasi tidak toksik.

\section{Referensi}

[1]. Ajrina, A., 2013, Uji Toksisitas Akut Ekstrak Metanol Daun Garcinia benthami Pierre Terhadap Larva Artemia salina Leach Dengan Metode Brine Shrimp Lethality Test (BSLT), Skripsi, Universitas Islam Negeri Syarif Hidayatullah.

[2]. Alam, G., 2002, Bhrine Shrimp Lethality Test (BST) sebagai Bioassay dalam isolasi senyawa bioaktif dari Bahan Alam, Majalah Farmasi dan Farmakologi, Vol 6(2).

[3]. Braguini, W. L., Natalia V. P., Bruno B. A., 2018, Phytochemical Analysis, Antioxidant Properties and Brine Shrimp Lethality of Unripe Fruits of Solanum viarum, Journal of Young Pharmacists, Vol. 10.

[4]. Dalimartha, S., 2007, Atlas Tumbuhan Obat Indonesia Jilid 3, Puspa Swara, Jakarta.

[5]. Depkes RI, 2008, Farmakope Herbal Indonesia, Departemen Kesehatan Republik Indonesia, Jakarta

[6]. Frengki, Roslizawaty, dan Desi P. 2014. Uji Toksisitas Ekstrak Etanol Sarang Semut Lokal Aceh (Mymercodia sp.) dengan Metode BSLT Terhadap Larva Udang Artemia salina Leach. Jurnal Medika Veterinaria. Vol. 8 (1) : 60-62.

[7]. Made, R., R., James, S., I., Made, D., S., 2013, Uji Toksisitas Dan Identifikasi Ekstrak Etanol Spons Callyspongia aerizusa Terhadap Larva Artemia salina L. Cakra Kimia (Indonesian E-Journal of Applied Chemistry), Vol 1 No 1.

[8]. Mutiah, Rona J. N., Terip K. K. 2018. Pembuatan Minuman Jeli Daun Kacapiring (Gardenia Jasminoides Ellis) Dengan Penambahan Karagenan. J. Rekayasa Pangan Dan Pert. Vol.6 (2).

[9]. Nuralifah, Asriullah Jabbar Parawansah, R. A. I. (2018). Uji Tosisitas Akut Ekstrak Etanol Daun Notika terhadap Larva artemia salina leach Metode BSLT. Pharmauho, 4(1), 1-5. 
[10]. Olowa, L. F. dan Olga M. N., 2013, Brine Shrimp Lethality Assay of the Ethanolic Extracts of Three Selected Species of Medicinal Plants from Iligan City Philippines, International Research Journal of Biological Sciences, Vol. 2(11).

[11]. Pangow, M. E., Widdhi B., Edwin D. Q. 2018. Skrining Fitokimia Dan Uji Toksisitas Dari Ekstrak Etanol Daun Manggis (Garcinia Mangostana L.) Dengan Metode Brine Shrimp Lethality Test (BSLT). Pharmacon-jurnal Ilmiah Farmasi. Vol. 7 (3)

[12]. Ratnani, R.D., Indah H., Yance A., Devi E.P., dan Dita D.D.K., 2015, Standardisasi Spesifik dan Non Spesifik Ekstraksi Hidrotopi Andrographolid dari Sambiloto (Andrographis paniculata), Prosiding Seminar Nasional Peluang Herbal Sebagai Alternatif Medicine, ISBN 978-602-19556-2-8.

[13]. Setyorini, H. A., Arifayu, A. K., Rosa, A., dan Winarsih., 2016, Karakterisasi Mutu Ekstrak Daun Sirsak (Annona murcata L.) dari Tiga Tempat Tumbuh, Buletin Penelitian Kesehatan, Vol. 44(4).

[14]. Suharti, N., Yossi G. L., dan Elidahanum H., 2017, Karakterisasi Simplisia dan Ekstrak Etanol Serta Uji Aktivitas Antioksidan Rimpang Jahe Merah (Zingiber Officinale Var. Vubrum Theilade) yang Diinokulasi Fungi Mikoriza Arbuskula (FMA), Jurnal Sains dan Teknologi Farmasi, Vol. 19 (1).

[15]. Sutomo, Nadya A., Arnida, dan Fadilaturrahmah, 2017, Studi Farmakognostik dan Uji Parameter Nonspesifik Ekstrak Metanol Kulit Batang Kasturi (Mangifera casturi Kosterm.), Jurnal Pharmascience, Vol. 4 (1).

[16]. Yunus I, Widdhi B Dan Edwin D.Q, 2018, Skrining Fitokimia Dan Uji Toksisitas Ekstrak Etanol Daun Langsat (Lansium Domesticum Corr) Terhadap Larva Artemia Salina Leach Dengan Metode Brine Shrimp Lethality Test (BSLT), PHARMACON jurnal Ilmiah Farmasi, Vol 7(3).

[17]. Zulharmita, Ummil K., dan Harrizul R., 2012, Pembuatan dan Karakterisasi Ekstrak Kering Daun Jambu Biji (Psidium guajava L.), Jurnal Farmasi Higea, Vol. 4 (2). 